\title{
Cardiac Maturation in an Hypoxic Milieu: Implications for Arrhythmias in Hypoxemic Defects
}

\author{
PHILIP POSNER, KENNETH N. PRESTWICH, AND DARYL D. BUSS
}

Department of Physiology, University of Florida, J. Hillis Miller Health Center, Gainesville, Florida 32610

\begin{abstract}
Newborn rabbits were raised in either hypoxic or normoxic environments for 3 months. Data from electrophysiological studies carried out on isolated sinoatrial and ventricular preparations from the two groups show that the hypoxic group had changes in cellular transmembrane electrical activity that could be the basis for disorders of rate and conduction in vivo. This model will be useful to study the etiology and therapy of some arrhythmias seen in cyanotic congenital hypoxemic heart disease. (Pediatr Res 19: 64-66, 1985)
\end{abstract}

Children born with cyanotic congenital heart disease are particularly susceptible to potentially lethal arrhythmias. Because of the improvements in palliative procedures and full surgical correction of hypoxemic heart disorders, more children are surviving the initial defect for longer periods of time. This increased survival time has led to an increasing incidence of arrhythmias that occur months or years after surgery. Two populations at particular risk of dysrhythmias are those who have had surgical correction of transposition of the great arteries, or of tetralogy of Fallot $(1,10,17)$. The incidence of postoperative arrhythmias in transposition approaches $50 \%$ or more, most of which are supraventricular in origin (17). In tetralogy of Fallot there is no published information on preoperative rhythm, but after surgical repair there is a relatively high incidence of ventricular arrhythmias including premature beats and tachycardia $(5,6,8)$. There are also reports of various supraventricular arrhythmias such as sinus bradycardia, wandering and ectopic pacemakers, premature beats, and tachyarrhythmias (18). In both of these hypoxemic lesions there is a relatively high incidence of sudden death probably due to lethal arrhythmias that occur months or years after corrective surgery.

The possible etiologies of these late lethal arrhythmias are: 1) genetically defective pacemaker and conduction tissue; 2) surgical damage to the pacemaker and conduction tissue $(4,7)$; and 3 ) hypoxemic damage to the pacemaker and conduction tissue, or a combination of these. There are currently no conclusive data to exclude any of these potential causes of dysrhythmias. In order to study one of these possible etiologies, a model was developed to study effects of chronic hypoxia on the developing neonatal cardiac pacemaker and conduction system.

Received February 2, 1984; accepted July 25, 1984.

Address all correspondence to Dr. Philip Posner, Department of Physiology, University of Florida, J. Hillis Miller Health Center, Gainesville, FL 32610.

This research was supported by a grant from the American Heart Association, Florida Affiliate. K.N.P. was a Fellow of the American Heart Association, Florida Affiliate.

\section{METHODS}

One-day-old New Zealand White Rabbits were placed in a chamber with an ambient $\mathrm{PO}_{2}$ of $65 \pm 3 \mathrm{~mm} \mathrm{Hg}$ and kept in this low $\mathrm{PO}_{2}$ environment for $23 \mathrm{~h}$ /day for 3 months. They were removed for $1 \mathrm{~h}$ each day so that they could nurse while their chamber was cleaned. The rabbit was chosen for this model of hypoxia in the neonate because of its unique suckling behavior. They normally suckle only once per day and receive their full milk allotment in 2-4 min $(9,12)$. Thus they can be exposed to hypoxic conditions for long periods and still be properly nourished. The $\mathrm{CO}_{2}$ in the chamber is absorbed by Indicating Baralyme (Chemtron Medical Division of Allied Healthcare, St. Louis, MO). The water vapor is absorbed by Indicating Drierite (W. A. Hammond, Xenia, $\mathrm{OH}$ ). The ambient $\mathrm{PO}_{2}$ was selected to give $\mathrm{PAO}_{2}$ values in the range of those recorded in congenital hypoxemic lesions. By using the equation $\mathrm{PAO}_{2}=\mathrm{PIO}_{2}-\left[\mathrm{PCO}_{2}\right.$ - (1-R) $\mathrm{FIO}_{2} / \mathrm{R}$ ] we can predict that the $\mathrm{PAO}_{2}$ is at most $40 \mathrm{~mm}$ $\mathrm{Hg}(14)$. The most obvious sign that our animals are hypoxemic is their color-ears, skin, conjunctiva, and noses have a distinct bluish tinge. The mean hematocrit was $54 \%$ as compared to $37 \%$ in the controls.

Control animals were reared at an ambient $\mathrm{PO}_{2}$ of $149 \mathrm{~mm}$ $\mathrm{Hg}$ (room air) and were permitted $1 \mathrm{~h} /$ day for nursing. At the end of 3 months the rabbits were anesthetized (pentobarbital sodium $65 \mathrm{mg} / \mathrm{kg}$, iv) and their hearts were removed. The sinus node-atrial region was dissected free and mounted in an isolated tissue bath maintained at $37^{\circ} \mathrm{C}$. The tissue was permitted to beat spontaneously while being superfused by modified Tyrode's solution $\left(\mathrm{NaCl}, 136.9 \mathrm{mM} ; \mathrm{KCl}, 3 \mathrm{mM} ; \mathrm{NaHCO}_{3}, 11.9 \mathrm{mM}\right.$; $\mathrm{NaH}_{2} \mathrm{PO}_{4}, 1.78 \mathrm{mM} ; \mathrm{Mg} \mathrm{Cl} 2,0.5 \mathrm{mM} ; \mathrm{CaCl}_{2}, 2.7 \mathrm{mM}$; glucose $5.55 \mathrm{mM})(13,16)$. Microelectrode recordings were made from pacemaker cells (true and subsidiary) and atrial myocardium (2, $11,13)$. Rate studies were carried out on pacemaker cells, while mapping was performed for all types of cells. The free wall of the right ventricle was also mounted for study and superfused. It was electrically driven at a rate of $70 \mathrm{bpm}$. Endocardial cells less than $1 \mathrm{~mm}$ deep were used in order to avoid studying cells that might be poorly supplied from the superfusate due to hypertrophy. In order to study the chronic effects caused by hypoxia, the superfusate was bubbled with $98 \% \mathrm{O}_{2}, 2 \% \mathrm{CO}_{2}(\mathrm{pH}=7.4)$. This permitted us to see the changes produced chronically as opposed to acute hypoxic changes that would be present with reduced oxygenation of the superfusate. Intracellular microelectrode recordings were made using standard techniques (15). The data were recorded and analyzed using a Nicolet Explorer III digital oscilloscope. The figures were reproduced with a Houston Instrument 100 plotter. The data on mean spontaneous sinus rate were obtained from eight hypoxically reared and eight normoxically reared rabbits matched for age and weight. The sino-atrial node/ 
atrial rhythm data were obtained from another group of five pairs matched for age and weight. Statistics were based on Student's $t$ test and the level of significance was defined as $\mathrm{p} \leq$ 0.05 . The ventricular data are from 19 hypoxically reared and seven normoxically reared rabbits.

\section{RESULTS}

The mean predominant spontaneous sinus rate (this was the basic rate determined over several minutes, excluding pauses and extra beats) in the hypoxic group $(n=25)$ was $83 \pm 4$ (SE) bpm. This was significantly less than $119 \pm 7(\mathrm{SE})$ in the control group $(n=10)$. In the preparations studied for rhythm, four of the five sino-atrial-node-atrial preparations showed continued periods of abnormal patterns of beating including bradycardia, tachycardia, pauses, blocks, and coupled beats. Rabbit 1 showed periods of couplets and a rate which varied between 100 and $180 / \mathrm{min}$ (Fig. $1 A$ ). Rabbit 2 showed pauses of over $800 \mathrm{~ms}$ and a rate range of $71-106 \mathrm{bpm}$. Rabbit 3 had a rate of 39-57 bpm (Fig. $1 B$ ). Rabbit 4 showed a rate of 32 recorded from the sinus region while a simultaneous impalement of the atrium showed a rate of 103 bpm (Fig. 2). None of these phenomena was observed in the controls. These data are summarized in Table 1. Since the microelectrode recordings came from subsidiary pacemaker cells $(2,13)$ and not from the true sinus pacemaker cell, these preliminary studies cannot define the cause of bradycardia as a failure in phase 4 automaticity or a nodal block (except in rabbit 4). Similarly we cannot tell whether the tachycardia is due to enhanced automaticity or reentry. However, it is clear that hypoxia can cause changes which result in supraventricular tachyarrhythmias and bradyarrhythmias.

The effect of chronic hypoxia on action potentials recorded from the right ventricular free wall removed from 19 rabbits reared in the manner described above as compared to seven controls is presented in Table 2 and Figure 3. Data were obtained from at least 10 different cells from various subendocardial sites (all less than $1 \mathrm{~mm}$ deep) in each preparation. While there was no significant difference in resting membrane potential, the tissue from the hypoxia-reared group showed a significantly lower

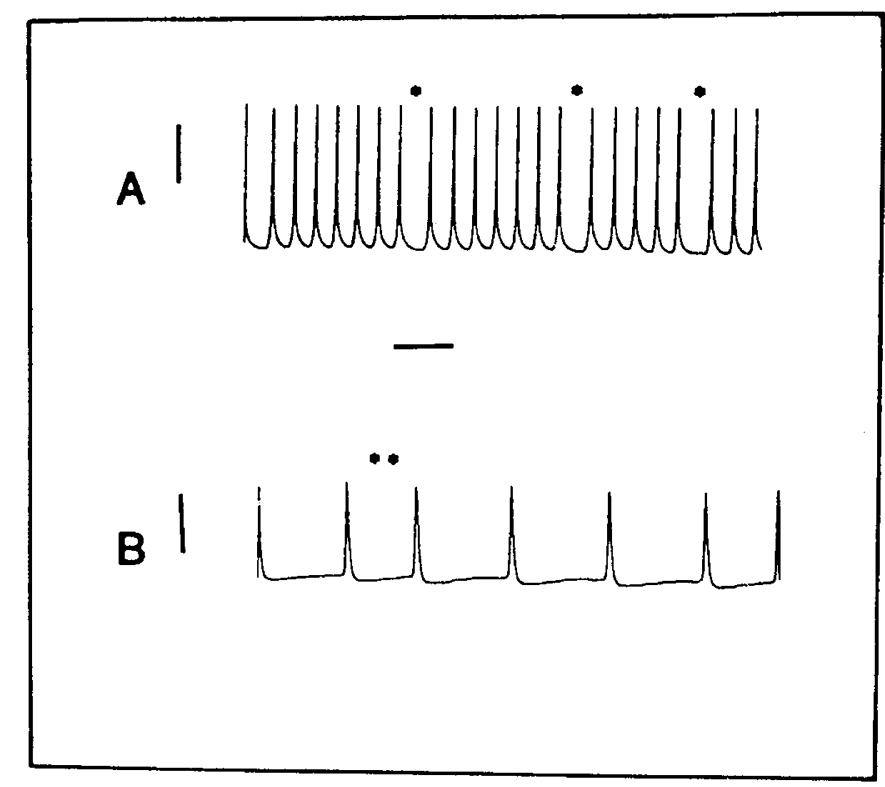

Fig. 1. The tracings are of intracellular recordings taken from the region of the S-A node-atrial junction in two different preparations from hypoxic rabbits. In $A$ the cycle length varies from $332 \mathrm{~ms}$ (unmarked) to $608 \mathrm{~ms}\left(^{*}\right)(180$ to $100 \mathrm{bpm})$. In $B$ the cycle length varies from $1086\left(^{* *}\right)$ to $1532 \mathrm{~ms}$ (unmarked) (57 to $39 \mathrm{bpm}$ ). The horizontal bar is $1 \mathrm{~s}$. The vertical bar runs from 0 to $-50 \mathrm{mV}$.

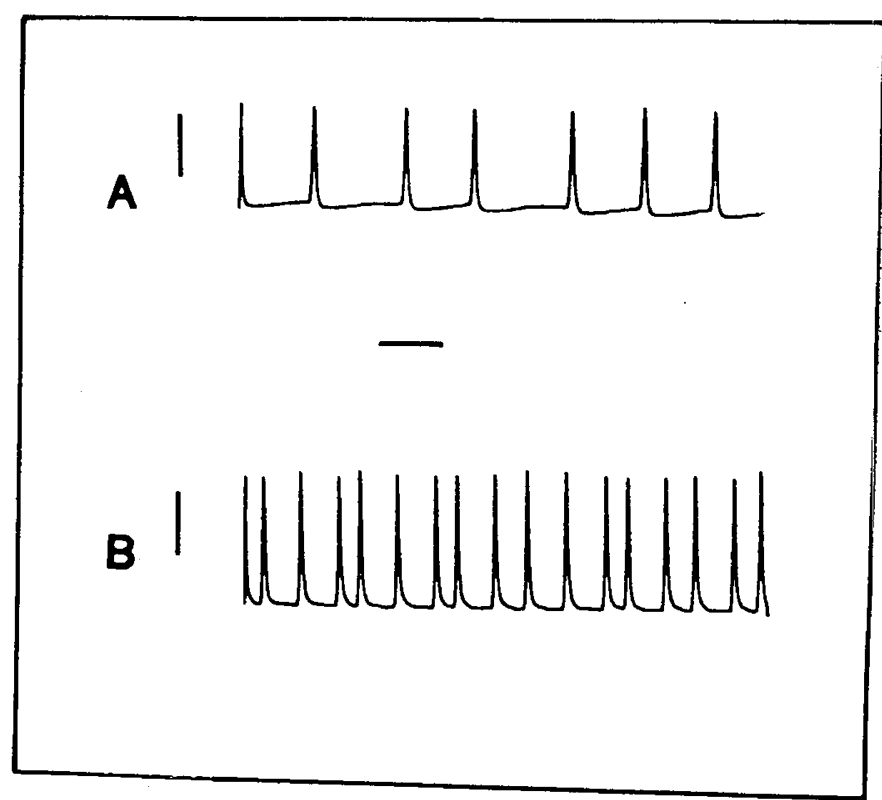

Fig. 2. The tracings in $A$ and $B$ were recorded simultaneously from the region of the S-A node-atrial junction. In $A$ the subsidiary pacemaker cell is firing at a cycle length of $1860 \mathrm{~ms}(32 \mathrm{bpm})$ while at the same time the myocardial cell in $B$ was firing at an average cycle length of 611 $\mathrm{ms}(98 \mathrm{bpm})$. The horizontal bar is $1 \mathrm{~s}$. The vertical bar runs from 0 to $-50 \mathrm{mV}$.

Table 1. Incidence of supraventricular rhythm disturbance

\begin{tabular}{lccccc}
\hline & & & & \multicolumn{2}{c}{$\begin{array}{c}\text { Coupled } \\
\text { beats }\end{array}$} \\
\hline Control $\ddagger$ & 0 & 0 & 0 & 0 & 0 \\
Hypoxic $\S$ & 20 & 3 & 1 & 9 & 3 \\
\hline
\end{tabular}

$* n=5$ rabbits, only verified by mapping.

$\dagger 10 \%$ longer than the normal cycle length.

$\ddagger n=10$ rabbits.

$\S n=25$ rabbits.

amplitude, maximum rate of rise of phase 0 , and a longer time to repolarize to $-70 \mathrm{mV}$. In the hypoxic preparations, there were always areas of cells that had lower than normal resting potentials, low action potential amplitudes and rates of rise of phase 0 , as well as prolonged durations when compared to the control rabbits. These areas sometimes showed afterpotentials (Fig. $3 C$ ). Concomitantly, there were cells with electrical characteristics close to those found in control cells. The control preparations never had these areas of "depressed" cells.

\section{DISCUSSION}

The cellular basis for conduction defects including reentrant beats may be depolarized cells, reduced action potential amplitude, reduced $\mathrm{dv} / \mathrm{dt}$ of phase 0 , nonhomogeneous refractory period, or afterpotentials (3). The major arrhythmias seen in hypoxemic congenital heart disease (conduction defects, bradyarrhythmias, tachyarrhythmias) have all been demonstrated in this model. Bradyarrhythmias may be due to reduced automaticity or conduction blocks between the sinus node and the atrial myocardium, but further studies are needed to delineate the precise mechanism of the bradyarrhythmias in this model. Tachyarrhythmias may be the result of enhanced automaticity, reentry, or afterpotential-based automaticity. The mechanism for enhanced rate presented here will be studied in future experiments. However, the requirements for reentry: slow conduction, unidirectional block, and dispersion of recovery can all occur in 
Table 2. The effect of chronic hypoxia on action potentials recorded from the right ventricular free wall

\begin{tabular}{|c|c|c|c|c|c|c|c|}
\hline & RMP* & AMP† & $\dot{\mathrm{V}}_{\max } \neq$ & $\mathrm{OmV} \S$ & $-50 \mathrm{mV} \S$ & $-70 \mathrm{mV} \S$ & AFT\| \\
\hline $\begin{array}{l}\text { Normoxic }(n=7) \\
\text { Hypoxic }(n=19)\end{array}$ & $\begin{array}{l}-79 \pm 3 \\
-75 \pm 5\end{array}$ & $\begin{array}{l}121 \pm 8 \\
108 \pm 9 \pi\end{array}$ & $\begin{array}{l}351 \pm 21 \\
236 \pm 581\end{array}$ & $\begin{array}{l}32 \pm 12 \\
41 \pm 16\end{array}$ & $\begin{array}{l}74 \pm 19 \\
85 \pm 27\end{array}$ & $\begin{array}{l}98 \pm 9 \\
138 \pm 11 \pi\end{array}$ & $\begin{array}{l}0 \\
5\end{array}$ \\
\hline
\end{tabular}

* Mean resting membrane potential $\pm \mathrm{SE}, \mathrm{mV}$.

$\dagger$ Mean action potential amplitude $\pm \mathrm{SE}, \mathrm{mV}$.

$\ddagger$ Mean maximum rate of rise of phase $0 \pm \mathrm{SE}$, v/s.

$\S$ Mean time to repolarize to ... $\pm \mathrm{SE}$, ms.

$\|$ Number of preparations with afterpotentials.

I Significantly different from control, $\mathrm{t}$ test, $\mathrm{p}<0.05$.
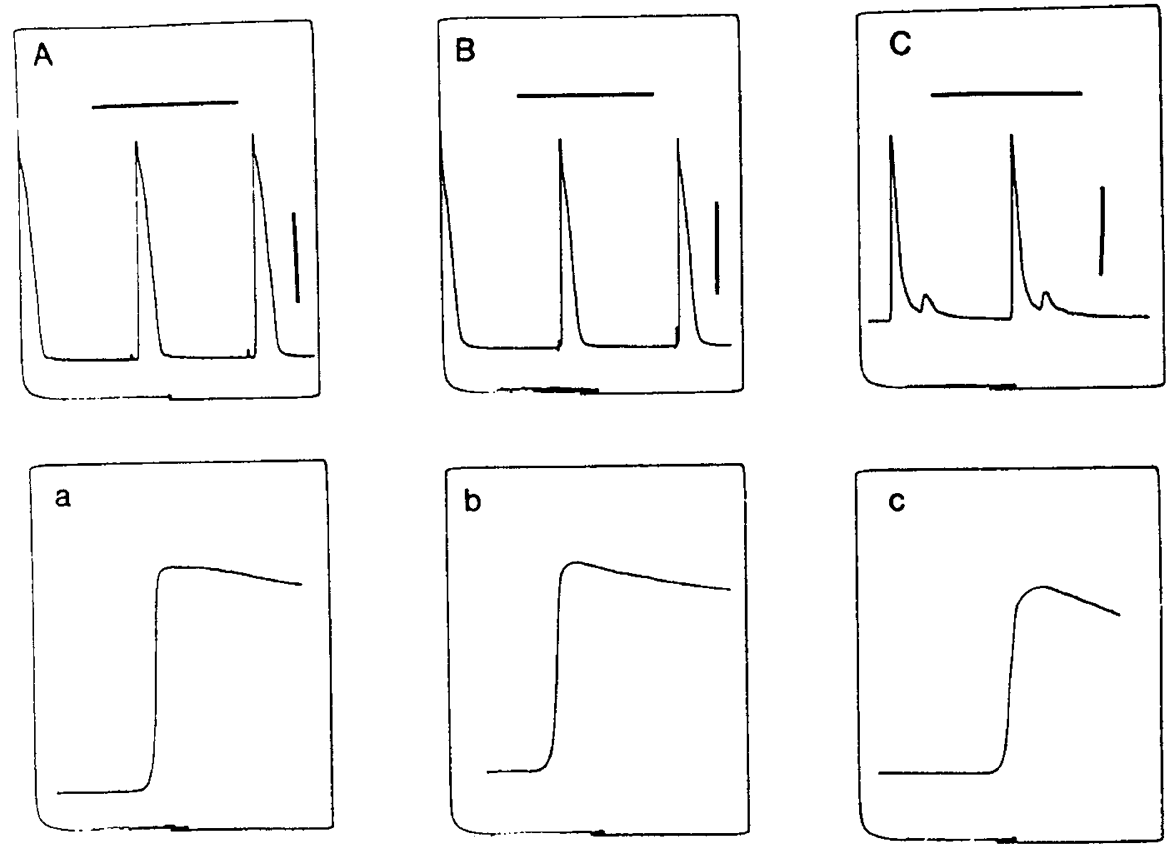

Fig. 3. The tracings are from the right ventricular free wall. The tissue is driven at $70 \mathrm{bpm}$. $A, a$ is from a control rabbit. $B, b$ and $C, c$ are from hypoxic rabbits. The horizontal lines are $1 \mathrm{~s}$. The vertical bars are 0 to $-50 \mathrm{mV} . a, b, c$ are fast sweeps of phase 0 used to measure $\dot{V}_{\max }$ of phase 0 $(a=350 \mathrm{v} / \mathrm{s}, b=240 \mathrm{v} / \mathrm{s}, c=198 \mathrm{v} / \mathrm{s})$. The tissue in $C$ was beating spontaneously at $70 \mathrm{bpm}$ and showed late after depolarizations.

cells with action potentials showing reduced amplitude, reduced $\mathrm{dv} / \mathrm{dt}$ of phase 0 and prolonged duration (3).

These characteristics, as well as a variability in ventricular action potential electrical parameters within single tissues, have been demonstrated in this model. This study was designed to test the hypothesis that chronic hypoxia during maturation could cause electrophysiological changes in the heart which were arrhythmogenic. However, the chronic hypoxia also may induce pulmonary hypertension, ventricular hypertrophy, and changes in autonomic outflow and reflexes. These factors may play a role in the electrophysiological changes. In addition, future studies with this model should address the acute effects of hypoxia as well as the chronic ones.

\section{REFERENCES}

1. Bink-Boelkens MThE, Velvis H, Homan Vonder Heide JJ, Eygelaar A, Hardjowijono RA 1983 Dysrhythmias after atrial surgery in children. Am Heart J 106:125

2. Brown H 1982 Electrophysiology of the sinoatrial node. Physiol Rev 62:505

3. Cranefield PF, Wit AL 1979 Cardiac arrhythmias. Ann Rev Physiol 41:459

4. Edwards WD Edwards JE 1978 Pathology of the sinus node in $d$-transposition following the Mustard operation. J Thorac Cardiovasc Surg 75:213

5. Garson A Jr, Gillette PC, Gutgesell HP, McNamara DG 1980 Stress-induced ventricular arrhythmia after repair of tetralogy of Fallot. Am J Cardiol 46:1006

6. Garson A Jr, Porter CJ, Gillette PC, McNamara DG 1983 Induction of ventricular tachycardia during electrophysiologic study after repair of tetralogy of Fallot. J Am Coll Cardiol 1:1493

7. Gillette PC, Kugler JD, Garson A, Gutgesell HP, Duff DF, McNamara DG 1980 Mechanisms of cardiac arrhythmias after the Mustard operation for transposition of the great arteries. Am J Cardiol 45:1225

8. Gillette PC, Yeoman MA, Mullins CE, McNamara DG 1977 Sudden death after repair of tetralogy of Fallot. Circulation 56:566

9. Hafez ESE (ed) 1970 Reproduction and Breeding Techniques for Laboratory Animals. Lea and Febiger, Philadelphia

10. Khoury GH, Shaher RM, Fowler RS, Keith JD 1966 Preoperative and postoperative electrocardiogram in complete transposition of the great vessels. Am Heart J 72:199

11. Kreitner D 1981 Electrophysiology of the sinoatrial node. Physiol Rev 62:312,37P

12. Lincoln DW 1974 Suckling: a time-constant in the nursing behavior of the rabbit. Physiol Behav 13:711

13. Lipsius S, Vassalle M 1978 Dual excitatory channels in the sinus node. J Mol Cell Cardiol 10:753

14. Otis AB 1964 Quantitative relationships in steady-state gas exchange. In: The Handbook of Physiology-Respiration I. The American Physiological Society, Washington, D.C. p 692

15. Posner P, Lambert CR, Farrar EL 1976 Inhibitory effects of catecholamines in canine cardiac Purkinje fibers. Am J Physiol 231:1415

16. Toda $N 1980$ Age-related changes in the transmembrane potential of isolated rabbit sino-atrial nodes and atria. Cardiovas Res 14:58

17. Vetter VL, Horowitz LN 1982 Electrophysiologic residua and sequelae of surgery for congenital heart defects. Am J Cardiol 50:588

18. Wessel HU, Bastanier CK, Paul MH, Barry TE, Cole RB, Muster AJ 1980 Prognostic significance of arrhythmia in tetralogy of Fallot after intracardiac repair. Am J Cardiol 46:843 